\title{
PREPOSISI BAHASA KARO
}

\author{
Herlina Ginting1, Candra Ronitua Gultom² \\ Universitas Sumatera Utara
}

\begin{abstract}
Abstrak
Penelitian ini bertujuan untuk mendsikripsikan preposisi yang terdapat dalam bahasa Karo. Subjek penelitian ini adalah masyarakat Karo yang berdomisili di ibu kota kabupaten Karo. Metode penelitian yang digunakan adlaah metode deskriptif kualitatif. Hasil penelitian tentang preposisi bahasa Karo adalah preposisi i 'di', bas 'pada', ku 'ke', nandangi 'terhadap', man 'kepada', nari 'dari', asangken 'daripada', seh 'sampai', alu 'dengan', man 'untuk', nandangi 'akan', tangtang 'tentang', perban 'karena', bagi 'seperti', ngikutken 'menurut'.
\end{abstract}

\section{Kata Kunci: Preposisi, Bahasa Karo}

\begin{abstract}
This study is to describe the preposition found out in Karo language. The subject is Karo society live in the Karo district. The method is qualitative descriptive. The result of the Karo's preposition is the preposition i 'on', bas 'to', ku 'to', nandangi 'to', man 'to', nari 'from', asangken 'than', seh 'to', alu 'with', man 'to', nandangi 'will', tantang 'about', perban 'because', bagi 'like', nigkutken 'according to'
\end{abstract}

\section{Keywords: Preposition, Karo Language}

\section{Pendahuluan}

Banyak ahli bahasa membuat definisi tentang perposisi atau yang sering juga disebut dengan kata depan, berikut ini akan kita kutip beberapa pendapat tentang definisi dari beberapa ahli bahasa.

"Kata depan menurut definisi tradisional, adalah kata yang merangkaikan kata-kata atau bagian-bagian kalimat". (Keraf, 1979:80)

"Perposisi atau kata depan adalah kata tugas yang bertugas sebagai unsur pembentuk frase preposisional." (Balai Pustaka, 1988:20)

"Preposisi adalah kata atau gabungan kata yang berfungsi menghubungkan kata atau frase sehingga terbentuk sebuah frase eksosentrik yang laizm menduduki fungsi keterangan di dalam kalimat.' (Chaer, 1987:23)

Dari ketiga pendapat tersebut di atas dapat kita lihat bahwa perposisi atau kata depan adalah kata atau gabungan kata yang menghubungkan (merangkaikan) bagianbagian kalimat sehingga terbentuk frase eksosentrik yang berfungsi menduduki fungsi keterangan dalam kalimat.

Sering orang beranggapan bahwa preposisi sama dengan konjungsi, padahal dalam kenyataannya ada perbedaan. Hal ini mungkin disesbabkan ada beberapa kata yang sama, yang dapat dipakai sebagai konjungsi dan preposisi.

Sebagai contoh kata karena:

1. Karena kesehatannya ia tidak masuk kerja

2. Karena sakit, ia tidak masuk kerja 
Kata karena pada kalimat yang pertama adalah preposisi karena terdapat dalam frase eksosentrik, sedangkan kata karena pada kalimat yang kedua adalah konjungsi karena menghubungkan kalimat sederhana ia sakit dan ia tidak masuk kerja.

Untuk lebih jelasnya berikut ini kita lihat uraian tentang ciri-ciri preposisi. Mengatakan bahwa kata depan memiliki ciri-ciri sebagai berikut:

a. Kata depan termasuk golongan partikel

b. Kata depan berfungsi sebagai penanda dalam frase eksosentrik

Secara semantik kata depan menandai pertalian antara kata frase yang mengikutinya, atau yang disebut petanda, dengan kata atau frase lain dalam kalimat atau frase yang lebih besar.

a. Kata depan termasuk golongan partikel maksudnya kata depan adlaah kata-kata yang tidak dapat berdiri sendiri sebagai subjek dan predikat. Istilah partikel di sini dipakai untuk menyatakan segolongan kata yang tidak mengalami infleksi.

b. Berdasarkan distribusinya frase dapat dibagi dua yaitu frase endosentrik dan frase eksosentrik. Pada frase endosentrik ada terdapat unsur pusat disebut atribut. Unsur pusat yaitu unsur yang dapat mewakili seluruh frase.

Contoh: sudah berkembang baik, akan terjadi.

Kata berkembang baik di atas merupakan unsur pusat dan kata sudah merupakan atribut. Deimikian juga dengan kata terjadi adalah merupakan unsur pusat dan kata akan merupakan atribut. Pada frase eksosentrik tidak terdapat unsur pusat dan atribut. Frase ini terdiri dari unsur langsung yang disebut penanda dan unsur langsung yang mengikutinya disebut petanda. Contoh: dari Jepang, dalam lemari.
Kata dari dan dalam pada contoh di atas disebut penanda kata jepang dan lemari disebut petanda.

c. Secara semantik kata depan menandai suatu pertalian antara kata atau frase yang mengikutinya. Hal ini dapat kita lihat dari contoh berikut:

Barang-barang dari Jepang terus mengalir ke Indonesia. Pada kalimat di atas dapat kita lihat kata depan dari menandai pertalian antara barangbarang dengan kata Jepang.

Pemakaian / penggunaan kata depan dalam bahasa Indonesia dan bahasa Karo umumnya sama. Baik ditinjau dari segi makna dan posisi. Hanya ada satu kata depan dalam bahasa Karo berbeda posisi pemakaiannya dengan bahasa Indonesia.

Kata depan nari dalam bahasa karo posisi penggunaannya diletakkan sesudah kata depan benda.

Contoh:

- Bapa reh Medan nari. 'bapak dating dari Medan'

- Buka enda kualoken bas guru nari. 'buku ini saya terima dari guru'

Sedangkan kata dari dalam bahasa Indonesia digunakan sebelum kata benda, seperti yang terlihat pada contoh di atas.

Secara morfologik ada tiga mcam bentuk preposisi (Chaer, 1987:23) yaitu: berupa kata seperti kata tugas I 'di' ku 'ke' dan nari 'dari'. Yang berupa gabungan kata antara lain berupa gabungan berderet seperti sue ras 'sesuai dengan' atau sentudu ras 'sesuai dengan' gabungan berpasangan seperti terdapat pada kalimat berikut ini:

Pagi-pagi nari seh keraben ia lelap dengedenge

'Dari pagi sampai sore ia terus merengekrengek'

Jakarta nari bapa lawes ku Mandao

'Dari Jakarta bapak pergi ke Manada'

Yang berasal dari kata lain, seperti kata ngikutken 'menurut'

Contoh: 
- Ulin akapana ngikutken kalak asangken nande bapa na.

'Lebih baik rasanya menurut pada orang lain daripada ibu bapanya'

- Ngikutken percakapen si lebe ulin timai kerina pulung

'Menurut pembiciraaan sebelumnya lebih baik tunggu semua hadir.'

Ditinjau dari segi semantik preposisi dapat dibagi atas beberapa golongan antara lain:

1. Menyatakan tempat dibagi lagi menjadi:

2. Menyatakan tempat berada, yaitu I 'di', bas 'dalam'

3. Menyatakan tempat asal, yaitu nari 'dari'

4. Menyatakan tempat tujuan. Yaitu ku 'ke' dan man 'kepada'

5. Menyatakan jarak waktu maupun jarak tempat, yaitu nari ku 'dari...ke' dan nari seh 'dari....sampai'

6. Menyatakan waktum yang dapat dibagi lagi menjadi:

7. Menyatakan waktu mulai, yaitu nari 'dari'

8. Menyatakan waktu tertentu, yaitu bas 'dalam, pada'

9. Menyatakan waktu akhir, yaitu seh 'sampai'

10. Menyatakan batas yaitu she 'hingga, sampai'

11. Menyatakan asal yaitu nari 'dari'

12. Menyatakan awal atau permulaan nari 'dari'

13. Menyatakan perbadingan yaitu bagi dan asangken

14. Menyatakan alat yaitu alu 'dengan'

15. Menyatakan tujuan yaitu man 'untuk, kepada, bagi, untuk, buat'

16. Menyatakan hal atau masalah yaitu nandangi 'akan, terhadap' tangtang 'tentang'
17. Menyatakan sebab yaitu kerna 'karena' dan perban 'karena' sabab 'sebab'

18. Menyatakan pernyataan yaitu ras 'dengan'

19. Menyatakan cara yaitu alu 'dengan'

20. Menyatakan rujukan yaitu ngikutken 'menurut', sue ras 'sesuai dengan' atau sentudu ras 'sesuai dengan'

\section{Penggunaan/Pemakaian/Perposis si dalam Bahasa Karo}

Berikut ini akan diuraikan penggunaan/pemakaian preposisi dalam bahasa Karo yang dikaitkan dengan makna.

1. Perposisi - /i/

Preposisi I 'di' dipergunakan untuk:

a. Menyatkan tempat berada digunakan di muka kata benda yang menyatakan tempat (seperti nama kota, ruang, desa dan sebagainya)

Contoh:

Kerja e iban I Gedung Wanita Karo 'pasti itu dibuat di Gedung Wanita Karo'

Mama erdahin I rumah Sakit Umum.

'Paman bekerja di Rumah Sakit Umum.'

b. Menyatakan tempat berada dengan lebih tepat, yaitu dengan menambahkan kata yang menujukkan bagian dari tempat yang dimaksud. Misalnya kata das atau datas 'atas', teruh 'bawah' bas 'dalam' dan sebagainya.

Contoh:

Surat kabar e amparken nande I das meja.

'surat kabar itu diletakkan ibu di atas meja

Uis si rebihnai enggo buniken I bas lemari.

'kain yang tadi malam sudah disimpan di dalam lemari' 
Preposisi I 'di' sebaiknya dibuat seperti kalimat berikut ini

Baju e lit I nande

;Baju itu ada di ibu'

Kalimat di atas kurang baik sebaiknya dibuat seperti kalimat berikut ini

Baju e lit bas nande

'baju itu ada pada ibu'

I wari kamis si reh kami berkat

'di hari kamis yang akan dating kami berangkat.'

Kalimat di atas kurang baik sebaiknya dibuat seperti kalimat berikut ini

Wari kamis si reh kami berkat

'hari kamis yang akan dating kami berangkat.'

2. Preposisi bas

Preposisi bas 'pada' dapat digunakan untuk:

a. Menyatakan tempat berada digunakan di depan kata benda yang menyatakan orang

Contoh:

Kitab e lit bas nande

'Buku itu ada pada ibu'

Bas aku lit uis si bagande

'pada saya ada kain seperti ini'

b. Menyatakn tempat dignukan di depan kata benda atau frase benda yang bukan menyatakan tempat yang sebenarnya.

Contoh:

Bas tiap-tiap rumah lit kuidah lampui gas

'pada tiap-tiap rumah ada saya lihat lampu petromak.'

Perbulangenna erdahin bas kantor pos

'Suaminya bekerja pada kantor pos'

c. Menyatakan waktu tertentu, digunakan di muka kata benda yang menyatakan waktu

Contoh:

Bas pukul lima pagi kam reh 'pada pukul lima besok kamu datang'

Smapati kami bas wari kamis si reh e

'Bantu kami pada hari kamis yang akan dating ini.'

Perposisi bas 'dalam' dapat digunakan untuk:

a. Menyatakan tempat berada digunakan di muka kata benda yang dianggap mempunyai ruang. Contoh:

Piga kalak sewaan bas bus si ndabuh nderbih?

'berapa orang penumpangnya dalam bus yang jatuh semalam?'

Uis e ibuniken bas lemari

'Kain itu disimpan dalam lemari.'

b. Menyatakan berada dalam satu situasi atau peristiwa, digunhakan di depan kata benda yang menyatakan hal atau proses

Contoh:

Bas perdalanen ndai lalit sitik pe obatna

'Dalam perjalanan tadi tidak ada sedikitpun hambatan'

Kam arus tutus bas sekolahndu

'Kamu harus serius dalam sekolah'

c. Menyatakan jangka waktu atau masa digunakan di depan kata bilangan

Contoh:

Bas piga-piga wari enda pagi nggo banci kerina galari

'Dalam beberapa hari ini sudah bisa dibayar semuanya'

Kubereken waktu bandu bas telu bulan enda

'kuberikan waktu kepadamu dalam tiga bulan ini

3. Preposisi $K u$

Preposisi ku 'ke' dapat digunakan untuk

a. Menyatakan tempat tujuan digunakan di muka kata benda yang menyatakan tempat 
Contoh:

Tiap wair nande lawes ku tiga 'setiap hari ibu pergi ke pasar' Agiku la banci reh ku rumahndu pagi

'adik saya tidak bisa datang ke rumahmu bseok.'

b. Menyatakan tempat tujuaan dengan lebih tepat, preposisi ke dengan kata yang menunjukkan tempat.

Contoh:

Piserken tas ah ku teruh meja 'geserkan ta situ ke bawah meja.'

Rempet kiamkenna bola e ku bas rumah

'tiba-tiba dilarikannya bola it uke dalam rumah.'

Preposisi ku 'ke' bsebaiknya tidak digunakan di depan kata ganti yang menyatakan orang (termasuk kata gantinya)

Contoh:

Mbarenda kam kang si mindu enampat ku aku

(sebaiknya: mbarenda kam kang mindo penampat man aku)

'dulu kamu juga yang minta tolong ke saya'

(sebaiknya: 'dulu kamu yang minta tolong kepada saya')

Ula kam lupa mbereken kunci e ku nande

(sebaiknya: ula kam lupa mbereken kunci e man nande)

'jangan kamu lupa memberikan kucni ini ke ibu'

(sebaiknya jangan kamu lupa memberikan kunci ini kepada ibu

4. Preposisi nandangi

Preposisi nandangi 'terhadap' dapat digunakan untuk:

a. Menyatakan sasaran perbuatan diletakkan di muka kata bedan yang manyatakan orang atau yang diorangkan. Kedudukannya

dapat digantikan dengan

preposisi man 'kepada'

Contoh:

La stitik pe aku mbiar nandangi

kam

'Tidak sedikitpun aku takut terhadap kamu'

Mbera-mbera tek ia nandangi

kita

'mudah-mudahan percaya dia terhadap kita'

b. Menyatakan prihal digunakan di muka kata benda abstrak

Contoh:

Nandangi ukurna pe ia lanai tek 'terhadap hatinya pun ia tidak percaya'

Patuh min kita nandangi kata dibata

'Hendaknya kita taat terhadap perintah Tuhan'

5. Preposisi man

Preposisi man 'kepada' dapat digunakan untuk menyatakan tempat yang dituju, digunakan di muka kata benda yang menyatakan orang atau yang diorangkan. Sedangkan perdikatnya mengandung pengertian tertuju terhadap sesuatu.

Contoh:

Kita arus mehamat man orang tua 'kita harus hormat kepada orang tua.' Adi patuh kam man orang tua $i$ pegedang dibata kap umurndu

'Kalau kamu taat kepada orang tua umurmu akan diperpanjang Tuhan'

6. Preposisi nari

Preposisi nari 'dari' dapat digunakan untuk:

a. Menyatakan asal tempat digunkaan sesduah kata benda yang menyatakan tempat.

Contoh:

Kalak ah reh kuta nari

'Mereka itu datang dari kampung' 
Melawensa ia reh sekolah nari

'Terlalu lama ia datang dari sekolah'

b. Menyatakan asla tempat dengan lebih tepat preposisi digunakan bersama-sama dengan kata yang menyatakan bagian mana dari tempat yang dimaksud. Kata nari digunakan setelah kata benda yang menyatakan tepmat sedangkan kata yang memperjalas arah digunakan di muka kata benda

Contoh:

Melala ndaraten dareh bas igungna nari

'Banyak keluar darah dari dalam hidungnya.'

Kunci e kubuat babo meja nari

'Kunci itu saya ambil dari atas meja

c. Menyatakan asal atau awal waktu, digunakan sesudah kata yang menyatakan waktu.

Contoh:

Karaban nari kam kutimai

'dari sore kamu saya tunggu'

Na inari ia enggo tading jenda.

'dari dulu dia sudah tinggal di sini.'

Buku enda kualoken bas bapa nari

'buku ini saya terima dari ayah'

7. Preposisi asangken

Preposisi asangken umumnya

digunakan untuk perbandingan

Contoh:

La ngenan atena megara e asangken si maratah ah

'dia lebih suka yang merah dari pada yang hijau itu.'

Gajangen agina asangken kakana

'Lebih tinggi adiknya daripada kakaknya.'

8. Preposisi seh

Preposisi seh 'sampai hingga' digunakan untuk menyatakan batas

Contoh:

Seh gundari ia lalap la reh 'sampai sekarang dai belum pernah datang'

Jenda nari seh duru ah belang jumana 'dari sini sampai ujung itu luas ladangnya'

Oge seh nomor siwah

'baca sampai nomor sembilan'

9. Preposisi alu

Preposisi alu 'dengan' dapat digunakan untuk:

a. Menyatakan alat, digunakan di muka kata benda yang menyatakan alat.

Contoh:

Bapa naka ranting alu kapak

'ayah membelah kayu dengan kempak'

Surat e isuratkenna alu mangsi

'surat itu diltulisnya dengan pensil'

b. Menyatakan cara atau keadaan, digunakan di muka kata sifat atau kata yang menyatakan suatu keadaan

Contoh:

Alu meriha uku ipesehken kami

'kami serahkan ini kepadamu'

Endik-endik agindu ena alu manjar-anjar

'bujuk adikmu itu dengan pelanpelan'

10. Preposisi man 'untuk'

Preposisi man 'untuk' digunakan untuk:

a. Menyatakan tujuan, digunakan di muka kata benda atau frase benda Contoh:

Karina asli di dahi kami man bandu

'semua hasil yang kami kerjakan ini adalah untuk kamu.'

Ia erdahin erguna man karina jelma

'dia bekerja berguna untuk semua manusia.' 
b. Menyatakan adanya pertalia perihal digunakan di muka kata benda atau frase benda

Contoh:

Man bana sen asa siden la lit ertina

'untuk dia uang sejumlah itu tidak ada artinya'

Iberkenna tenda mata man kalak setutus ibas dahin e.

'diberikannya kenang-kenangan untuk orang yang rajin dalam tugas itu

11. Preposisi nandangi

Preposisi nandangi 'akan' digunakan untuk menyatakan objek dalam kalimat

Contoh:

Kami sitik pe lanani tek nandangi janji-janjindu e

'kami sedikitpun tidak percaya akan janji-janjimu itu'

12. Preposisi tangtang

Preposisi tangtang 'tentang' digunakan untuk menyatakan hal atau masalah, digunakan di muka kata benda atau frase benda

Contoh:

Perban nandina sakit, ia la reh ku sekolah

'karena ibunya sakit, ia tidak datang ke sekolah.'

Kaka la surung reh perban melala dahinna

kakak tidak jadi datang karena banyak pekerjaannya.'

13. Preposisi bagi

Preposisi bagi 'seperti' dipakai untuk menyatakan perbandingan atau persamaan, digunakan di muka kata benda atau frase benda

Contoh:

Pertawana pe bagi lenggur ciger wari 'caranya tertawa serperti petir di siang hari.'

Ula nai ulihindu dahinndu bagi si enggo lepas

'jangan lagi kau ulangi pekerjaan seperti yang sudah lewat.'

14. Preposisi ngikutken

Preposisi ngikutken 'menurut' dipaakai untuk menujukkan suatu landasan pernyataan, digunakan di muka kata benda atau frase benda dan letaknya di awal kalimat.

Contoh:

Ngikutken perarihenta si arah lebe maka sekalenda si dungi kerina

'menurut perjanjian kita terdahulu maka hari ini kita selesaikan semuanya.'

\section{KESIMPULAN}

Dari uraian pada baba sebelumnya dapat ditarik kesimpulan bahwa preposisi dalam bahasa Karo mempunyai banyak kesamaan dengan preposisi dalam bahasa Indonesia. Hal ini dapat dilihat dari posisi preposisi yaitu dapat diikuti oleh kata atau frase nominal, kata atau frase verbal, kata atau frase bilangan, kata atau frase keterangan. Selain itu juga dapat dilihat dari pemakaian preposisi dalam kalimat dan makna yang ditimbulkannya. Perbedaan yang ditemukana dalah posisi penggunaaan ialah posisi penggunaan selalu diikuti oleh kata atau frase, tetapi preposisi nari 'dari' dalam bahasa karo mengikuti kata atau frase.

\section{DAFTAR PUSTAKA}

Alek \& Achmad. 2011. Bahasa Indonesia untuk Perguruan Tinggi. Jakarta: Prenada Media Group 
Chaer, Abdul. 1987. Preposisi dan Konjungsi. Flores: Nusa Indah

Keraf, Gorys. 1982. Tata Bahasa Indoensia. Flores: Nusa Indah

Kridalaksana, Harimurti. 1983. Kamus Linguistik. Jakarta: Gramedia

Ramlan, M. 1982. Kasta Depan atau Preposisi dalam Bahasa Indonesia. Yogyakarta: Karyono

Ramlan, M. 1978. Sintaksis. Yogyakarta: Karyono

Slametumulyana. 1957. Kaidah Bahasa Indonesia. Jakarta: Djambatan

Woollams, Geoff. 2004. Tata Bahasa Karo. Medan: Penerbit Bina Media Perintis

Wojowasito. S. 1976. Pengantar Sintaksis. Bandung: Shinta Dharma 